\title{
Analysis of appropriate tetanus prophylaxis in an Emergency Department
}

\author{
Acil serviste yapılan tetanoz proflaksisi uygunluğunun analizi
}

\author{
Gözde ŞİMŞEK, ${ }^{1}$ Erol ARMAĞAN, ${ }^{1}$ Özlem KÖKSAL, ${ }^{1}$ Yasemin HEPER, ${ }^{2}$ \\ Suna ERAYBAR POZAM, ${ }^{1}$ Vahide Aslıhan DURAK ${ }^{1}$
}

\section{BACKGROUND}

In this study, our aim was to identify the validity of the prophylaxis indications for patients who received tetanus prophylaxis, determine the ratio of high-risk wounds to the number of patients with immunity, and to evaluate the tetanus immunity of specific age groups.

\section{METHODS}

Patients who applied to the Emergency Department (ED) between September 2009 and May 2010 and who were considered for tetanus prophylaxis by his/her primary care physician were included in the study.

\section{RESULTS}

A total of 320 patients were evaluated. The average age of the patients was $40.87 \pm 15.83$ years. A total of $73.1 \%$ of the patients were male and $26.8 \%$ were female. A total of $40.3 \%$ of the patients knew their vaccination history, while $59.7 \%$ had no recollection of their vaccination history. $14.7 \%$ of the patients had received their last dose within 5 years and $48.1 \%$ within $5-10$ years; $37.2 \%$ of the patients declared that more 10 years had passed since their last vaccination. In $75 \%$ of the patients, the tetanus immunoglobulin (Ig)G level was identified as $\geq 0.1 \mathrm{IU} / \mathrm{ml}$, while $25 \%$ of the patients had levels $<0.1 \mathrm{IU} / \mathrm{ml}$. The number of patients with protective levels was lower among those who were illiterate or who had only a primary school education, and this difference was statistically significant $(\mathrm{p}<0.001)$.

\section{CONCLUSION}

The vaccination histories can be misleading. Certain equipment can be used at the bedside to determine a patient's tetanus immunization status.

Key Words: Emergency department; immunization; tetanus.

\section{$\boldsymbol{A M A C}$}

$\mathrm{Bu}$ çalışmada, tetanoz profilaksisi verilen hastaların profilaksi endikasyonunun doğruluğu, hekim tarafından tetanoz riskli kabul edilen yaraların ve bu hastaların bağışıklık oranının belirlenmesi, belirli yaş gruplarının tetanoz bağışıklığının değerlendirilmesi amaçlandı.

\section{GEREÇ VE YÖNTEM}

Eylül 2009-Mayıs 2010 tarihleri arasında Uludağ Üniversitesi Tıp Fakültesi Acil Servis'ine (AS) başvuran ve birinci basamak hekimi tarafindan tetanoz profilaksisi verilmesi uygun görülen hastalar bu çalışmaya alındı.

\section{BULGULAR}

Toplam 320 hasta değerlendirildi. Hastaların yaş ortala-

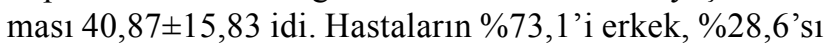
kadındı. Hastaların \%40,3'ü aşılama geçmişini biliyorken, \%59,7'si aşılanma geçmişini hatırlamıyordu. Hastaların \%14,7'si son dozunu beş yıl içinde alırken, \%48,1'i 5-10 yıl içinde almıştı ve \%37,2'si 10 yıldan daha fazla bir süre önce son kez aşılanmıştı. Hastaların \%75'inde tetanoz immünglobulin (Ig)G düzeyi $\geq 0,1 \mathrm{IU} / \mathrm{ml}$ ve $\% 25$ 'inde tetanoz IgG düzeyi $<0,1 \mathrm{IU} / \mathrm{ml}$ olarak saptand. Okuma yazma bilmeyenlerde ya da sadece ilkokul mezunu olanlarda tetanoz bağışıklı̆̆ı için koruyucu düzeyler daha düşüktü ve bu fark istatistiksel olarak anlamlı idi $(\mathrm{p}<0,001)$.

\section{SONUÇ}

Hastalardan alınan aşılanma öyküleri yanıltıcı olabilir ve bu amaçla hastaların yatak başı tetanoz bağışıklık durumunun test edilebileceği cihazlar kullanılabilir.

Anahtar Sözcükler: Acil servis; bağışıklık durumu; tetanoz.
Departments of ${ }^{1}$ Emergency Medicine, ${ }^{2}$ Enfectious Diseases, Uludag University Faculty of Medicine, Bursa, Turkey.
Uludağ Üniversitesi Tıp Fakültesi, ${ }^{1}$ Acil Tıp Anabilim Dalı, ${ }^{2}$ Enfeksiyon Hastalıkları Anabilim Dal1, Bursa.

Correspondence (Illetişim): Özlem Köksal, M.D. Uludağ Üniversitesi Tıp Fakültesi, Acil Tıp Anabilim Dalı, Görükle Yerleşkesi, 16059 Bursa, Turkey. Tel: +90 - 224 - 2953222 e-mail (e-posta): koksalozlem@gmail.com 
Tetanus is a disease characterized by difficulty in swallowing, trismus, opisthotonus posture, and tonic clonic contractions that are usually exacerbated by external stimuli. ${ }^{[1]}$ The cases are usually acute and often fatal. ${ }^{[2]}$ Globally, the groups considered to be at risk for tetanus are uninoculated adult women, the geriatric population, individuals with low education, intravenous drug abusers, people with altered immune systems, and newborns. ${ }^{[3-6]}$

Protection against tetanus is antibody-dependent, and immunization can be conferred by active or passive immunization. Tetanus toxoid is a modified neurotoxin that induces the production of a protective antitoxin. ${ }^{[7]}$ The antitoxin levels decrease with time. Tetanus vaccination is part of the Expanded Immunization Program (EIP) in Turkey. Tetanus vaccination is a hyperimmune globulin that is indicated for people who are at risk for tetanus and lack a history of vaccination. This is because the immunity that tetanus toxoid confers is a delayed process. Tetanus Immune Globulin (TIG) provides immunity by driving the unbound tetanus toxin away. ${ }^{[1,4,8,9]}$ Human Tetanus Immune Globulin (HTIG) is made from humans and is the first choice for immunization. ${ }^{[10]}$

Another point regarding the prevention of tetanus is the appropriate treatment of patients who present to the Emergency Department (ED). ${ }^{[11-13]}$ In cases of acute injuries, the Centers for Disease Control (CDC) in the United States relies on the properties of the wound and the immunization history of the patient (Table 1) to determine the recommendations for tetanus prophylaxis. [14] While determining the immunization status, it is important to identify whether the patient has completed a primary vaccination. If a patient's vaccination history or the history of the previous doses is unknown, it should be assumed that the patient has received no tetanus toxoid dose. These patients require TIG as well as tetanus toxoid during the cleaning and debridement of dirty and large wounds. In cases of clean and small wounds, active immunization with tetanus toxoid is sufficient and passive immunization is not necessary. ${ }^{[7,15]}$ In patients with a history of insufficient vaccina- tion, as part of their wound care, the continuation of active immunization should be ensured, and primary vaccination must be completed. ${ }^{[12,14,16]}$

In this study, our aim was to identify the validity of the prophylaxis indications for patients who received tetanus prophylaxis, determine the ratio of high-risk wounds to the number of patients with immunity, evaluate the tetanus immunity of specific age groups, and determine whether prophylaxis is necessary even when vaccinations have been administered in less than a five-year period and when the wounds are clean. Our main goal was to clarify those patient groups to whom tetanus prophylaxis must be administered. We sought to investigate the questions of a) whether prophylaxis should be administered according to the patient's vaccination history and presence of a high-risk wound for tetanus, and b) whether factors such as the patient's age and accompanying comorbidities should be considered.

\section{MATERIALS AND METHODS}

The study was conducted in Uludağ University Medical School Hospital, Department of Emergency Medicine, after approval from the ethics council was received. Patients who applied to the Department of Emergency Medicine of Uludağ University Medical School Hospital between September 2009 and May 2010 and who were considered for tetanus prophylaxis by his/her primary care physician were included in the study. In total, over a nine-month period, 365 patients who were considered candidates for tetanus prophylaxis were included in the study. Patients who were referred from other hospitals or who were administered prophylaxis in another hospital, those who were unwilling to cooperate, and those who did not want to take part in the study were excluded.

Patients who presented to the ED with an injury were evaluated according to the trauma protocol. The patient was informed of the study if the resident had decided to administer tetanus prophylaxis after the initial treatment was given. Patients who agreed to participate in the study were asked to sign informed consent forms. The information relating to the pa-

Table 1. The immunization history of the patient ${ }^{\ddagger}$

\begin{tabular}{lllll}
\hline & \multicolumn{2}{c}{ Clean, minor wound } & \multicolumn{2}{c}{ All other wounds } \\
\hline History of tetanus immunization & Tdap or Td* & TIG & Tdap or Td* & TIG \\
Uncertain or $<3$ doses & Yes & No & Yes & Yes \\
$\geq 3$ doses & No & No & No & No \\
& Unless $>10$ years & & Unless $>5$ years & last dose \\
& since last dose & & & \\
& No & & & \\
\hline
\end{tabular}

TIG: Tetanus immune globulin; Tdap: Tetanus, diphtheria, and pertussis; Td: Tetanus-diphtheria; TT: Tetanus toxoid. * Tdap is preferred to Td for adolescents who have never received Tdap. Td is preferred to TT for adolescents who received Tdap previously or when Tdap is not available. $\neq$ Advisory Committee on Immunization Practices (ACIP) recommendations. 
tients who were included in the study was noted by the emergency resident who evaluated the patient in a form called "Evaluation of the Validity of Administering Tetanus Prophylaxis in the Emergency Ward". In this form, the patient's age, gender, birth place, place of residence, level of education, compulsory military service history, vaccination information, history of diabetes or steroid use, location of the injury, depth of the injury, duration of the injury, presence and type of infection, and whether or not the wound was considered high risk for tetanus were recorded.

After consent was given and the patient information was entered into the form, prior to the tetanus vaccination, $4-5 \mathrm{cc}$ of venous blood was drawn. The blood was centrifuged for 5 minutes at $3000 \mathrm{rpm}$, and the serum obtained was placed in Eppendorf tubes and stored at $-83{ }^{\circ} \mathrm{C}$ at the Uludag University Medical School Blood Center until analysis. Tetanus antibody levels were determined in the Uludağ University Department of Microbiology and Infection ELISA laboratory using the Clostridium tetani 5S IgG ELISA kit (Novatec Immundiagnostica GmBH, Germany), according to manufacturer's instructions. Individuals with antitoxin levels $<0.1 \mathrm{U} / \mathrm{ml}$ were considered to have insufficient immunity, whereas levels $>0.1 \mathrm{U} /$ $\mathrm{ml}$ were to be considered protective against tetanus. For these levels, the current guidelines were used as a reference. ${ }^{[6,16-18]}$

For the analysis, the Statistical Package for the Social Sciences (SPSS) 13.0 program for Windows was used. The descriptive statistics and frequency distributions were calculated according to the properties of the variables in the study. For comparison of categorical variables, Pearson chi-square and Fisher's absolute chi-square tests were used. Statistical significance was set at $\mathrm{p}<0.05$.

\section{RESULTS}

A total of 365 patients were included in the study; 25 patients were excluded because the serum samples were lost, and 20 patients were excluded because the forms on which the information was gathered were lost. As a result, 320 patients were evaluated in this study. The average age of the patients was $40.87 \pm 15.83$ (1086 years). The majority of the patients who applied to the ED were in their third decade of life. Two hundred thirty-four of the patients (73.1\%) were male, and 86 $(26.8 \%)$ were female. The distribution of the individuals according to age group is shown in Figure 1.

In this study, the evaluated wound characteristics included the depth and type of wound, time interval passed since the injury, presence or not of infection in the wound, type of infection, and whether or not the wound was considered as high risk for tetanus. In total, $153(47.8 \%)$ patients had injuries in an up-

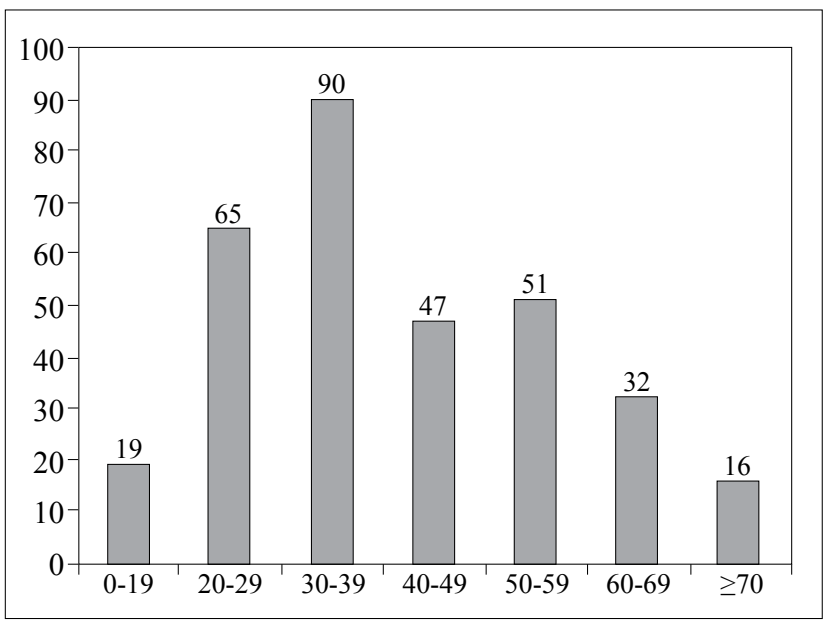

Fig. 1. The distribution of the individuals according to age group.

per extremity, whereas $74(23.1 \%)$ had injuries in a lower extremity. Thirteen (4.1\%) patients had injuries in multiple locations. The injuries were classified according to the type of the wound as laceration, abrasion, avulsion, piercing by an object, firearm injury, crush wound, bite wound, and burn wound. Of 320 patients, 137 (42.8\%) had lacerations, whereas only 2 $(0.6 \%)$ had firearm injuries. Thirteen $(4.1 \%)$ patients had more than one type of injury (Table 2). The depths of the injuries were classified as superficial, subcutaneous, facia/tendon, and bone/joint. Superficial injuries were the most common, representing 196 (61.2\%) of the injuries, followed by subcutaneous and bone/ joint injuries, representing 74 (23.1\%) and 34 (10.6\%), respectively.

Table 2. The type and localization of injury

\begin{tabular}{lcc}
\hline & $\begin{array}{c}\text { Number } \\
\text { (n) }\end{array}$ & $\begin{array}{c}\text { Percent } \\
(\%)\end{array}$ \\
\hline Localization of injury & & \\
Head/Neck & 66 & 20.6 \\
Trunk & 42 & 13.1 \\
Perineum & 5 & 1.5 \\
Upper extremity & 153 & 47.8 \\
Lower extremity & 74 & 23.1 \\
>1 localization & 13 & 4.06 \\
Type of injury & & \\
Laceration & 137 & 42.8 \\
Abrasion & 30 & 9.3 \\
Avulsion & 20 & 6.25 \\
Stab wound & 37 & 11.5 \\
Firearm injury & 2 & 0.6 \\
Crush injury & 24 & 7.5 \\
Bite wound & 78 & 24.4 \\
Burn wound & 7 & 2.2 \\
>1 type & 13 & 4.06 \\
\hline
\end{tabular}


Table 3. The tetanus vaccination history

\begin{tabular}{lccc}
\hline Vaccination history & Duration & Number $(\mathrm{n})$ & Percent $(\%)$ \\
\hline Known & $<5$ years & 19 & 5.9 \\
& $5-10$ years & 62 & 19.4 \\
& $>$ 10 years & 48 & 15 \\
& Total & 129 & 40.3 \\
Unknown & & 191 & 59.7 \\
Total & & 320 & 100 \\
\hline
\end{tabular}

Regarding the duration that had passed since the injury, $259(80.9 \%)$ of the patients declared that they presented to the hospital within the first 6 hours. A total of $129(40.3 \%)$ patients knew their vaccination history, while 191 (59.7\%) had no recollection of their vaccination history. Of the 129 patients who knew their vaccination history, $19(14.7 \%)$ had received their last dose within 5 years, $62(48.1 \%)$ had been vaccinated within $5-10$ years and $48(37.2 \%)$ declared that more 10 years had passed since the last vaccination (Table 3).

Regarding comorbidities such as immunosuppressive drug use or diabetes mellitus (DM), which might affect the immunity, $40(12.5 \%)$ patients had DM, and $4(1.3 \%)$ were using immunosuppressive drugs. In 240 of the patients $(75 \%)$, the tetanus immunoglobulin ( $\mathrm{Ig})$ G level was identified as $\geq 0.1 \mathrm{IU} / \mathrm{ml}$, while $80(25 \%)$ patients had tetanus IgG levels $<0.1 \mathrm{IU} / \mathrm{ml}$.

When the gender distribution with respect to age was analyzed, with the exception of the 51-60 years of age group ( $\mathrm{p}=0.01)$, there was no statistically significant difference between the groups (Table 4). When the education level was considered, the number of patients with protective levels was lower among those who were illiterate or who had only a primary school education, and this difference was identified to be statistically significant $(p<0.001)$. The summary of the relationship between tetanus and immunization status is summarized in Table 5.

\section{DISCUSSION}

Tetanus is one of the main diseases that can be prevented via vaccination. Although active immunization against tetanus is included in the national vaccination program and vaccination is performed during pregnancy and compulsory military service, tetanus continues to occur. This may be because supplementary dosages are not given regularly, and deficiencies in the application of prophylaxis for tetanus-related injuries are present. The lack of continuation of tetanus immunization is the most important factor affecting the

Table 4. The gender distribution of immunization status with respect to age

\begin{tabular}{|c|c|c|c|c|c|c|}
\hline \multirow[t]{3}{*}{ Age } & \multicolumn{6}{|c|}{ Immunization status } \\
\hline & \multicolumn{2}{|c|}{ Tetanus IgG $<0.1 \mathrm{IU}$} & \multicolumn{2}{|c|}{ Tetanus IgG $\geq 0.1 \mathrm{IU}$} & \multicolumn{2}{|c|}{ Total } \\
\hline & Number (n) & Percent (\%) & Number (n) & Percent (\%) & Number (n) & Percent (\%) \\
\hline \multicolumn{7}{|l|}{$<40^{*}$} \\
\hline Male & 15 & 11.5 & 116 & 88.5 & 131 & 100 \\
\hline Female & 4 & 8.0 & 46 & 92.0 & 50 & 100 \\
\hline \multicolumn{7}{|l|}{$41-50^{\#}$} \\
\hline Male & 8 & 23.6 & 26 & 76.4 & 34 & 100 \\
\hline Female & 5 & 41.7 & 7 & 58.3 & 12 & 100 \\
\hline \multicolumn{7}{|l|}{$51-60^{\alpha}$} \\
\hline Male & 14 & 31.8 & 30 & 68.2 & 44 & 100 \\
\hline Female & 8 & 72.8 & 3 & 27.2 & 11 & 100 \\
\hline \multicolumn{7}{|l|}{$61-70^{*}$} \\
\hline Male & 11 & 64.8 & 6 & 35.2 & 17 & 100 \\
\hline Female & 5 & 83.4 & 1 & 16.6 & 6 & 100 \\
\hline \multicolumn{7}{|l|}{$>71^{\psi}$} \\
\hline Male & 5 & 62.5 & 3 & 37.5 & 8 & 100 \\
\hline Female & 5 & 71.5 & 2 & 28.5 & 7 & 100 \\
\hline
\end{tabular}

*,\#, ¥, $\psi: \mathrm{p}>0.05 ; \alpha \mathrm{p}=0.01$. 
Table 5. Relationship between education level and immunization status

\begin{tabular}{|c|c|c|c|c|c|c|}
\hline \multirow[t]{3}{*}{ Education level } & \multicolumn{6}{|c|}{ Immunization status } \\
\hline & \multicolumn{2}{|c|}{ Tetanus IgG $<0.1 \mathrm{IU}$} & \multicolumn{2}{|c|}{ Tetanus IgG $\geq 0.1 \mathrm{IU}$} & \multicolumn{2}{|c|}{ Total } \\
\hline & Number (n) & Percent (\%) & Number (n) & Percent (\%) & Number (n) & Percent (\%) \\
\hline Illiterate & 8 & 47.1 & 9 & 52.9 & 17 & 100 \\
\hline Primary school & 30 & 41.7 & 42 & 58.3 & 72 & 100 \\
\hline Elementary school & 19 & 31.1 & 42 & 68.9 & 61 & 100 \\
\hline High school & 14 & 14.6 & 82 & 85.4 & 96 & 100 \\
\hline College & 9 & 12.2 & 65 & 87.8 & 74 & 100 \\
\hline Total & 80 & 25 & 240 & 75 & 320 & 100 \\
\hline
\end{tabular}

occurrence of the disease. Because immunization can be provided by supplementary vaccinations, tetanus prophylaxis is one of the most important steps in preventing the disease. ${ }^{[13]}$ For this reason, we evaluated the validity of the tetanus prophylaxis administered in the ED and investigated the immunization status of the patient population.

Various tetanus case evaluations have been reported by different centers throughout Turkey. In three previously conducted studies, it was reported that most of the patients were above the age of 45 years on average and had failed to apply to a health institution after an injury. Furthermore, primary immunization was deficient in $70 \%$ of the cases. As a result of these studies, the importance of adult immunization and prophylaxis after a trauma was emphasized. ${ }^{[19-21]}$ Ergönül et al. ${ }^{[22]}$ examined 34 previous cases and demonstrated that adult vaccination and training are important. A study conducted in the Kocaeli region of Turkey demonstrated that the level of protection in the $<40$ years of age group is $95.1 \%$, whereas in the $>40$ age group, this level is $65.6 \% .^{[23]}$ In a study that evaluated the level of protection in 100 people over the age of 18 , $93.1 \%$ in the 18-30 age group were protected, and this proportion decreased with age to $20 \%$ among people in their 70 s. ${ }^{[24]}$ In a study involving 2,094 patients in three provinces, Kurtoğlu et al. ${ }^{[25]}$ found the highest level of protection to be in the 10-19 years of age group. In a study involving 249 people over the age of 40 , Öztürk et al. ${ }^{[26]}$ found the level of protection to be $25.3 \%$. While the percentage of protected individuals in the $40-49$ age group was $38.2 \%$, the proportion was $19.4 \%$ among individuals over 60 . In a similar study conducted in the Manisa province, the antitoxin levels of individuals aged 17-72 years were measured. In a total of 143 people, 107 (74.8\%) had protective levels, whereas $12(8.4 \%)$ were weakly positive and 24 $(16.8 \%)$ had negative antitoxin levels. ${ }^{[27]}$ The common findings in all these studies indicate that the decreasing level of tetanus antibody protection with age, lack of supplementary vaccinations in later years, decrease in the immune response, and related tetanus toxoid response can be addressed by vaccination of the older population, vaccination of young people at school, vaccination of males undergoing compulsory military service, vaccination of pregnant women, and by development of vaccination programs for adults. Consistent with these studies, we found that the level of antibody detection decreases with age and that age is an important risk factor for tetanus immunity.

When the level of education of the patients in our study was analyzed, we found that illiterate individuals and primary school graduates were less likely to have protection against tetanus toxin than those with high school and college degrees, and this difference was found to be statistically significant $(p<0.001)$. Similar to our results, in a study conducted in the United States, it was found that a higher level of education was associated with an increased likelihood of having an immune response to tetanus. ${ }^{[6]}$ In another study conducted in Edirne, it was also found that individuals who were illiterate and primary school graduates were less likely to be protected than middle school and high school graduates. It was also demonstrated that the illiterate population generally consisted of older individuals who had lower antitoxin levels. ${ }^{[28]}$ Other studies that have been conducted in our country have also shown that the level of education is related to an increased likelihood of protection against tetanus. ${ }^{[23,26]}$ This result is correlated with an increased frequency of visits to healthcare providers, a lower number of minor traumas, and a higher rate of hospital admission among women during pregnancy, which has been observed in individuals with a higher education level. Additionally, considering that $56 \%$ of the individuals over 60 who were included in our study were illiterate or primary school graduates, the low level of education of the elder population may explain the low levels of antibodies in this population.

In previous studies investigating the relationship between tetanus antibody levels and underlying comorbidities, conflicting results have been obtained. In 
our study, we evaluated the individuals who had DM or used a steroid group drug. Among the patients with DM, 12 of $40(30 \%)$ had protective antibody levels $\geq 0.1 \mathrm{IU} / \mathrm{ml}$, and the levels of antibodies with respect to individuals who did not have DM were found to be significantly different $(\mathrm{p}<0.001)$. In our study, there were only four individuals who were using steroid drugs, and two of them (50\%) had antibody levels that were under the protective level. The lack of statistical significance of this finding can be attributed to the low number of patients involved in the study.

One of the most important steps in the evaluation of patients entering the ED is the application of tetanus prophylaxis. The Advisory Committee on Immunization Practices (ACIP) has listed the indications for tetanus prophylaxis in routine wound care and has provided recommendations. ${ }^{[14]}$ According to these recommendations, it is important to first distinguish whether a wound is considered high risk for tetanus. Classical guidelines specify that minor traumas are not at high risk for tetanus. However, some studies have shown that both major and minor injuries may be at risk for tetanus. In our study, $75.3 \%$ of the 320 cases were deemed to be at risk for tetanus. Of these, $73.4 \%$ of the patients had protective levels of antibodies. A total of $79.7 \%$ of the 79 patients who were not considered to be at risk for tetanus had protective levels of antibodies.

As seen from previous studies, tetanus is a disease that can be prevented with a highly protective vaccination. However, due to the problem of adherence to the vaccination programs in developing countries, maternal and neonatal tetanus, and tetanus in the elder population in developed countries, this disease continues to be a cause of mortality. In our study, we have shown that tetanus immunization, especially after the age 40 , can only be provided with supplementary vaccinations.

Emergency services are a key factor in the accomplishment of this task. According to our study, patients over 40 must receive tetanus prophylaxis if they have not completed primary immunization, have not received a vaccination dose within 10 years, have diabetes, or have a wound that is at risk for tetanus. It is difficult to distinguish whether a wound is at risk for tetanus. In previously published studies, it has been shown that tetanus develops in $30 \%$ of minor injuries. It has also been demonstrated that most of the tetanus cases are observed in individuals who do not receive care for their wound or who do not present to the hospital after an injury. We believe that the public should be informed about this issue. This study and other studies have shown that the level of protection among individuals who do not recall their vaccination history is approximately $70 \%$. Because of this, the vaccination histories can be misleading. This further demonstrates the important role of medical records. The dates of previous vaccinations must be recorded. Additionally, certain equipment can be used at the bedside to determine a patient's tetanus immunization status. The validity of these tests and their cost-effectiveness in an ED setting should be investigated, and their usage should be more widespread. This way, unnecessary vaccinations in younger people can prevented.

Conflict-of-interest issues regarding the authorship or article: None declared.

\section{REFERENCES}

1. Gençer S. Kuduz ve tetanoz profilaksisi. Toplumdan edinilmiş enfeksiyonlara pratik yaklaşımlar. Sempozyum Dizisi 2008;61:223-34. [Article in Turkish]

2. Bleck TP. Clostridium tetani. In: Mandell GL, Douglas RG, Bennett JE, editors. Principles and practice of infectious diseases. 5th edition. New York: Churchill Livingstone; 2000. p. 2537-43.

3. Felek S, editör. Sistemik enfeksiyon hastalıkları. İstanbul: Nobel; 2000.

4. CDC. Tetanus. In: Atkinson W, Hamborsky J, McIntyre L, Wolfe S, editors. Epidemiology and prevention of vaccinepreventable diseases. 10th ed. Washington DC: Public Health Foundation; 2007. p. 71-80.

5. Centers for Disease Control and Prevention (CDC). Tetanus among injecting-drug users-California, 1997. MMWR Morb Mortal Wkly Rep 1998;47:149-51.

6. Gergen PJ, McQuillan GM, Kiely M, Ezzati-Rice TM, Sutter RW, Virella G. A population-based serologic survey of immunity to tetanus in the United States. N Engl J Med 1995;332:761-66.

7. Preventing Tetanus, Diphtheria, and Pertussis Among Adolescents: Use of Tetanus Toxoid, Reduced Diphtheria Toxoid and Acellular Pertussis Vaccines MMWR 55 No. 2006 RR3:1-50.

8. Alagappan K, Rennie W, Narang V, Auerbach C. Immunologic response to tetanus toxoid in geriatric patients. Ann Emerg Med 1997;30:459-62.

9. Rhee P, Nunley MK, Demetriades D, Velmahos G, Doucet JJ. Tetanus and trauma: a review and recommendations. J Trauma 2005;58:1082-8.

10. Hsu SS, Groleau G. Tetanus in the emergency department: a current review. J Emerg Med 2001;20:357-65.

11. Giangrasso J, Smith RK. Misuse of tetanus immunoprophylaxis in wound care. Ann Emerg Med 1985;14:573-9.

12. Capellan O, Hollander JE. Management of lacerations in the emergency department. Emerg Med Clin North Am 2003;21:205-31.

13. Stubbe M, Mortelmans LJ, Desruelles D, Swinnen R, Vranckx M, Brasseur E, et al. Improving tetanus prophylaxis in the emergency department: a prospective, double-blind cost-effectiveness study. Emerg Med J 2007;24:648-53.

14. CDC. Preventing tetanus, diphtheria, and pertussis among adults: use of tetanus toxoid, reduced diphtheria toxoid and acellular pertussis vaccines. Recommendations of the Advisory Committee on Immunization Practices (ACIP). MMWR 2006; 55 (No. RR-17):1-34.

15. Diphtheria, tetanus, and pertussis: recommendations for vaccine use and other preventive measures. Recommendations of the Immunization Practices Advisory committee (ACIP). 
MMWR Recomm Rep 1991;40:1-28.

16. McQuillan GM, Kruszon-Moran D, Deforest A, Chu SY, Wharton M. Serologic immunity to diphtheria and tetanus in the United States. Ann Intern Med 2002;136:660-6.

17. Borrow R, Balmer P, Roper MH. The immunological basis for immunization series. Module 3: tetanus update 2006. World Health Organization, Geneva, Switzerland; 2007. http://www.who.int/vaccines-documents/DocsPDF07/869. pdf.

18. Crone NE, Reder AT. Severe tetanus in immunized patients with high anti-tetanus titers. Neurology 1992;42:761-4.

19. Saltoglu N, Tasova Y, Midikli D, Burgut R, Dündar IH. Prognostic factors affecting deaths from adult tetanus. Clin Microbiol Infect 2004;10:229-33.

20. Salman C, Sekban N, Döşemeci L, Cengiz M, Yılmaz M, Ramazanoğlu A. Yoğun bakımımızda tetanoz: Onyedi hastada tedavi, komplikasyonlar ve mortalitenin değerlendirilmesi. Türk Anest Rean Der Dergisi 2007;35:200-8.

21. Çelik M, Solakoğlu C, Taştan E, Erol E, Şenel N.A. Tetanoz olgularımız. Ulusal Travma Dergisi 1995;1:189-91.

22. Ergonul O, Erbay A, Eren S, Dokuzoguz B. Analysis of the case fatality rate of tetanus among adults in a tertiary hospital in Turkey. Eur J Clin Microbiol Infect Dis 2003;22:188-90.

23. Dundar V, Yumuk Z, Ozturk-Dundar D, Erdoğan S, Gacar G. Prevalence of tetanus immunity in the Kocaeli Region, Turkey. Jpn J Infect Dis 2005;58:279-82.

24. Ergönül O, Sözen T, Tekeli E. Immunity to tetanus among adults in Turkey. Scand J Infect Dis 2001;33:728-30.

25. Kurtoglu D, Gozalan A, Coplu N, Miyamura K, Morita M, Esen $\mathrm{B}$, et al. Community-based seroepidemiology of tetanus in three selected provinces in Turkey. Jpn J Infect Dis 2004;57:10-6.

26. Oztürk A, Göahmetoğlu S, Erdem F, Mýsgüroğlu Alkan S. Tetanus antitoxin levels among adults over 40 years of age in Central Anatolia, Turkey. Clin Microbiol Infect 2003;9:33-8.

27. Yegane TS, Atman Ü, Kasırga E. İleri yaşlarda tetanus aşısı rapeli gerekli mi? Türk Mikrobiyol Cem Derg 2003;33:14852.

28. Tansel O, Ekuklu G, Eker A, Kunduracilar H, Yuluğkural Z, Yüksel P. Community-based seroepidemiology of diphtheria and tetanus in Edirne, Turkey. Jpn J Infect Dis 2009;62:2758. 